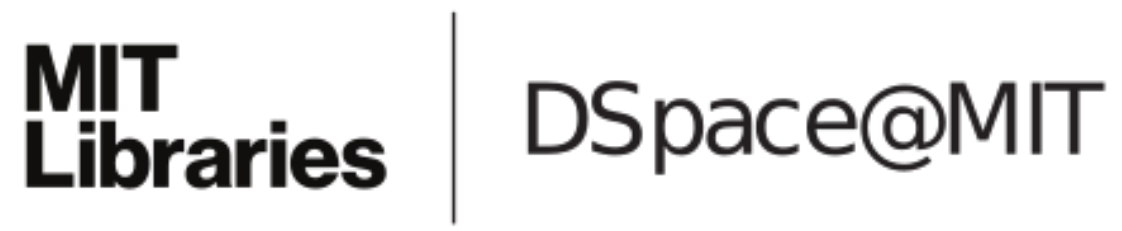

\author{
MIT Open Access Articles
}

\author{
Visible Hands: Governance of Value \\ Creation-Within Firms and Beyond
}

The MIT Faculty has made this article openly available. Please share how this access benefits you. Your story matters.

Citation: Gibbons, Robert. "Visible Hands: Governance of Value Creation-Within Firms and Beyond." American Economic Association Papers and Proceedings 110 (May 2020): 172-176.

As Published: http://dx.doi.org/10.1257/pandp.20201066

Publisher: American Economic Association

Persistent URL: https://hdl.handle.net/1721.1/130275

Version: Final published version: final published article, as it appeared in a journal, conference proceedings, or other formally published context

Terms of Use: Article is made available in accordance with the publisher's policy and may be subject to US copyright law. Please refer to the publisher's site for terms of use. 


\title{
Visible Hands: \\ Governance of Value Creation-Within Firms and Beyond
}

\author{
By RoBERT GibBOns*
}

In 1977, Alfred Chandler published The Visible Hand: The Managerial Revolution in American Business. His thesis was clear from the title and elaborated in the second paragraph:

In many sectors of the economy the visible hand of management replaced ... the invisible hand of market forces. ... $[\mathrm{M}]$ odern business enterprise took over the functions of coordinating flows of goods through existing processes of production and distribution, and of allocating funds and personnel for future production and distribution (p. 1).

The book won Bancroft and Pulitzer Prizes and became a cornerstone of business history. Yet Chandler can be seen as understating the domain of visible hands: economic value is created by management, rather than by market forces, in many settings besides firms.

I will argue that taking a unified view of the many domains in which visible hands operate not only is more coherent than the conventional distinction between firms versus markets but also yields insights into what visible hands do and what research needs to be done.

\footnotetext{
* MIT Sloan School (email: rgibbons@mit.edu). This essay draws from conversations with Daron Acemoglu, Dan Barron, Rebecca Henderson, Kate Kellogg, Spencer Pantoja, Mike Powell, Woody Powell, Larry Prusak, Nelson Repenning, Ed Schein, John Sterman, Cat Turco, Barry Weingast, Sid Winter, and Ezra Zuckerman. More generally, I am enormously grateful for two decades of intellectual stimulation and financial liberation provided by the people and resources of MIT Sloan's Program on Innovation in Markets and Organizations; I hope some of that support is reflected here.

${ }^{\dagger}$ Go to https://doi.org/10.1257/pandp.20201066 to visit the article page for additional materials and author disclosure statement.
}

\section{Visible Hands beyond Firms}

First, there are of course many managed organizations besides firms: hospitals, schools, government agencies, and more. Presumably Chandler would have counted these as further examples of visible hands.

Continuing with single organizations, other examples include political parties and legislatures. Perhaps Chandler would not have seen managers in these organizations, but if the distinction is between visible versus invisible hands, parties and legislatures are not run by the latter. Weingast and Marshall (1988) captured this in "Why Legislatures, Like Firms, Are Not Organized as Markets."

Second, some activities are organized, but not within a single organization. As the simplest case, consider two firms in an alliance or a hand-in-glove supply relationship: managers again may create value, now by managing the relationship between the firms.

In short, nonintegration is not always "the market." Instead, nonintegration may be another domain for visible hands-or "private ordering" (Williamson 2002, p. 438). As Richardson (1972) argued,

Firms are not islands but are linked together in patterns of co-operation and affiliation. Planned co-ordination does not stop at the frontiers of the individual firm but can be effected through co-operation between firms. The dichotomy between firm and market, between directed and spontaneous co-ordination, is misleading (p. 895).

Third, consider collaboration among several entities that may not be firms-such as a government, a university, and an established business seeking to spur entrepreneurship in its region. This is Ostrom's (2010, p. 1) "polycentric 
governance," which here will mean collaboration among three or more entities, at least two of which cannot merge.

Some communities are similar to polycentric governance, in the sense that members aren't going to merge, even though in principle they could. Ellickson's (1991) cattle ranchers and Bernstein's (1992) diamond merchants develop and enforce their own system of dispute resolution. Such collaboration within communities is again "private ordering."

To summarize, Simon (1991, pp. 27-28) envisioned

A mythical visitor from Mars ... equipped with a telescope that reveals social structures. The firms reveal themselves ... as solid green areas .... Market transactions show as red lines connecting firms. ...

Organizations would be the dominant feature of the landscape. A message sent back home ... would speak of "large green areas interconnected by red lines." It would not likely speak of "a network of red lines connecting green spots." ...

When our visitor came to know that the green masses were organization and the red lines ... market transactions, it might be surprised to hear the structure called a market economy. "Wouldn't 'organizational economy' be the more appropriate term?" it might ask?

Like Chandler, Simon focused on firms, omitting many other settings run by visible rather than invisible hands. In supply relationships, polycentric governance, communities, and beyond, management may be more important than markets in creating value. Because Simon's "organizational" economy is much bigger than just its firms, we need a new name. Let's try "governance economy."

\section{The Governance Economy?}

In a beautiful essay, Dixit (2009) discusses "Governance Institutions and Economic Activity." By governance institutions, Dixit means "the legal and social institutions that support economic activity and economic transactions by protecting property rights, enforcing contracts, and taking collective action to provide physical and organizational infrastructure" (p. 5, emphasis added).

In partial contrast, Williamson often refers to governance structures, as opposed to governance institutions. For example, Williamson (2002, p. 438) observes that

even if the polity has fashioned good rules of the game, transactions of an idiosyncratic kind ... are ones for which simple market exchange is poorly suited. Private ordering efforts by the parties, to ... embed transactions in more protective governance structures, have the purpose and effect of mitigating the contractual problems that would otherwise arise.

Taking the "rules of the game" to be Dixit's "institutions," in many settings there remain opportunities for gaming by the parties, leading to "private ordering efforts" to mitigate "the contractual problems that would otherwise arise." A classic example is parties choosing to conduct a transaction under integration that would otherwise result in wasteful haggling under nonintegration, but the many examples above of visible hands under nonintegration show that integration is far from the only instance of private ordering.

To summarize, Dixit (2009) focuses on governance that supports transactions, Williamson on governance of transactions. For Dixit, institutions may be enforced by third parties, whereas for Williamson (2002), private ordering is done by the parties themselves. But this distinction can be blurry: Ellickson's (1991) cattle ranchers and Bernstein's (1992) diamond merchants are subject to governance institutions that they themselves enforce, so Dixit can see them as a governance institution and Williamson as private ordering.

Fortunately, Dixit (2009, p. 5) notes that "as with any buzzword, everyone understands the concept [of governance] a little differently. This is unavoidable, so I will just give my definition for the purpose of this article, and leave it at that." Grateful for this license, I will do the same, hewing closer to Williamson than Dixit: seeking a word less linked to firms than "management," in this essay I will say that "governance" is what visible hands do. 


\section{What Do Visible Hands Do?}

So, in the pursuit of value creation, what do visible hands actually do? Let's start within firms: because managers have authority, perhaps orders are given and actions follow. Outside economics, the opposite view has long held sway. For example, Barnard (1938, p. 167) notes that "there is no principle of executive conduct better established in good organizations than that orders will not be issued that ... will not be obeyed."

Cyert and March (1963 [1992], pp. 205-06) provides more detail:

[T] he business firm is basically a coalition without a generally shared, consistent set of goals. Consequently, we cannot assume that a rational manager can treat the organization as a simple instrument ... . Just as he needs to predict and attempt to manipulate the "external" environment, he must predict and attempt to manipulate his own firm. Indeed, our impression is that most actual managers devote much more time and energy to ... managing their coalition than they do to ... dealing with the outside world.

Discussing organizational routines as a “truce," Nelson and Winter (1982, p. 111) illustrates what a manager may be up against:

[T] he terms of a truce can never be fully explicit .... . [They become] defined by a shared tradition arising out of the specific contingencies confronted and the responses of the parties to those contingencies....

\begin{abstract}
[A] contemplated action otherwise sensible both for the organization and for the member taking it may have to be rejected if it is likely to be interpreted as ... signaling a lessened commitment to the preservation of the truce. ...

Adaptations that appear "obvious" and "easy" to an external observer may be foreclosed because they involve a perceived threat to internal political equilibrium.
\end{abstract}

Mintzberg (2004) distills these and other academic writings and corporate experiences into a crisp distinction between analysis (deciding what to do) and administration (getting the organization to do it), emphasizing that the latter is the core of management.

In all of these accounts-from Barnard (1938) to Cyert and March (1963 [1992]) to Nelson and Winter (1982) to Mintzberg (2004) and beyond - the organization is not a "simple instrument." We should not be surprised by this. After all, Coase's (1937) question (something like, "if markets were perfect, why would we need firms?") tells us to expect imperfect contracting in settings where organizations are even contemplated as alternatives to markets. As a result, "orders" may be problematic, coalitions may be difficult to mobilize, "political equilibrium" may prevent efficient adaptation, and administration (getting the organization to get something done) may be a central challenge. I'

All this suggests that administration/management/governance may be hard and take time, but we have not yet described what visible hands actually do. To my ear, Nelson and Winter's words suggest part of the answer: if a "political equilibrium" is holding the organization back, perhaps management's task is to build (not select) a new equilibrium.

\section{Building an Equilibrium}

Gibbons and Henderson (2012) argues that "relational contracts"-informally, a shared understanding of the parties' roles in and rewards from collaborating together; formally, an equilibrium of a repeated game-are central to many high-performing organizations but face two problems. First, and well understood, is the credibility problem: should you believe the promise I am making you? Second, and essentially unstudied, is the clarity problem: do we have a shared understanding of the promise I intend to be making you? ${ }^{2}$

Some of the classic work on management practices surfaced related issues. For example, in a study of steel finishing lines, Ichniowski, Shaw, and Prennushi (1997, p. 308) reports,

Our interviews revealed how a low level of labor-management trust in older lines rendered ineffective new work practices like information sharing,

\footnotetext{
${ }^{1}$ See Gibbons (forthcoming) for details.

${ }^{2}$ Gibbons and Prusak (2020) discusses how stories might help with the clarity problem.
} 
productivity-improvement teams, and employment security. For example, the manager at one older line observed: "It's just difficult to change attitudes in old plants with a history of tension and mistrust. We now share financial information with workers, but some workers still believe there are two sets of books."

Similar issues arise in Turco's (2016) fascinating ethnography of a firm with a very active internal wiki. In terminology akin to organizational economics's, the founders are sharing voice rights with the employees, but this raises the question of whether they are also sharing decision rights: for example, is the firm a democracy, with voting via the wiki? The founders decide that they are not sharing decision rights, raising the question of whether employees will continue to contribute to the wiki without knowing if their comments will matter. The founders assert that they will take wiki comments into account, raising both the credibility and clarity problems.

And to return to our beginning - namely, visible hands beyond one firm-Frydlinger, Hart, and Vitasek (2019) describes initial and ongoing processes for building "formal relational contracts" between firms. They propose substantial work on the clarity problem before the deal is signed and then on ongoing processes designed to produce shared responses to both unanticipated events and misunderstandings that surface. Frydlinger, Hart, and Vitasek (2019) applies this process to contracting between firms (or other contracting parties), but much of their method could be equally productive between two entities inside an organization (absent the formal part of the contract).

Part of the reason that the firms in Gibbons and Henderson (2012) are high performing may be that they have built an equilibrium that is hard to copy. Part of the reason that old steel lines in Ichniowski, Shaw, and Prennushi (1997) find new work practices ineffective may be that they are stuck in a bad equilibrium. Part of the reason for the tension in Turco's (2016) firm may be the interplay between the credibility and clarity problems. Part of the reason for the initial and ongoing processes in Frydlinger, Hart, and Vitasek (2019) may be the difficulty in building and updating an equilibrium.

As Shona Brown, senior vice president at Google in the 2000s, described the effort to build that organization, "We were trying to build a new equilibrium. It was fragile; we had to reinforce it every day." 3

\section{Conclusion}

I have suggested that economic transactions can be divided into three categories. First, (1) those that are priced versus (2) those that are governed by visible hands. And second, within the latter, $(2 \mathrm{a})$ those within a single organization versus $(2 b)$ those in nonintegrated settings. To repeat, nonintegration is not always "the market" (i.e., (1)).

I agree with Richardson that the conventional distinction between markets versus firms, (1) versus (2a), is misleading-because it either omits (2b) or, worse, conflates it with (1). For $m e$, the fundamental distinction is between pricing versus governance, (1) versus (2). Unifying (2a) with (2b) highlights the commonalities between Turco's (2016) wiki and Frydlinger, Hart, and Vitasek's (2019) contracts: they are both struggles to build an equilibrium. What does it mean to build an equilibrium, or for it to be fragile or reinforced? Those practicing governance are telling us we need more work on these issues.

\section{REFERENCES}

Barnard, Chester. 1938. The Functions of the Executive. Cambridge, MA: Harvard University Press.

Bernstein, Lisa. 1992. "Opting out of the Legal System: Extralegal Contractual Relations in the Diamond Industry." Journal of Legal Studies 21 (1): 115-57.

Chandler, Alfred D., Jr. 1977. The Visible Hand: The Managerial Revolution in American Business. Cambridge, MA: Belknap Press.

Coase, R. H. 1937. "The Nature of the Firm." Economica 4 (16): 386-405.

Cyert, Richard M., and James G. March. 1963. A Behavioral Theory of the Firm. Oxford, UK: Blackwell Publishers. [1992].

-Dixit, Avinash. 2009. "Governance Institutions and Economic Activity." American Economic Review 99 (1): 5-24.

\footnotetext{
${ }^{3}$ Personal communication.
} 
Ellickson, Robert C. 1991. Order without Law: How Neighbors Settle Disputes. Cambridge, MA: Harvard University Press.

Frydlinger, David, Oliver Hart, and Kate Vitasek. 2019. "A New Approach to Contracts: How to Build Better Long-Term Strategic Partnerships." Harvard Business Review, September-October. https://hbr.org/2019/09/anew-approach-to-contracts.

Gibbons, Robert. Forthcoming. "March-ing toward Organizational Economics." Industrial and Corporate Change.

Gibbons, Robert, and Rebecca Henderson. 2012. "Relational Contracts and Organizational Capabilities." Organization Science 23 (5): 1350-64.

Gibbons, Robert, and Laurence Prusak. 2020. "Knowledge, Stories, and Culture in Organizations." AEA Papers and Proceedings https:// doi.org/10.1257/pandp.20201091.

Ichniowski, Casey, Kathryn Shaw, and Giovanna Prennushi. 1997. "The Effects of Human Resource Management Practices on Productivity: A Study of Steel Finishing Lines." American Economic Review 87 (3): 291-313.

Mintzberg, Henry. 2004. Managers, Not MBAs.
San Francisco, CA: Berrett-Koehler Publishers. Nelson, Richard R., and Sidney G. Winter. 1982. An Evolutionary Theory of Economic Change. Cambridge, MA: Belknap Press.

-Ostrom, Elinor. 2010. "Beyond Markets and States: Polycentric Governance of Complex Economic Systems." American Economic Review 100 (3): 641-72.

Richardson, G. B. 1972. "The Organisation of Industry." Economic Journal 82 (327): 88396.

-Simon, Herbert A. 1991. "Organizations and Markets." Journal of Economic Perspectives 5 (2): 25-44.

Turco, Catherine J. 2016. The Conversational Firm: Rethinking Bureaucracy in the Age of Social Media. New York: Columbia University Press.

Weingast, Barry R., and William J. Marshall. 1988. "The Industrial Organization of Congress; or, Why Legislatures, Like Firms, Are Not Organized as Markets." Journal of Political Economy 96 (1): 132-63.

-Williamson, Oliver E. 2002. "The Lens of Contract: Private Ordering." American Economic Review 92 (2): 438-43. 